\title{
Elaboration of Libertarianism takes the view of humanity in the dual profession law
}

Elaborasi Libertarianisme Berparadigma Kemanusiaan

Pada Hukum Rangkap Profesi Dokter-Advokat Indonesia

Gregorius Yoga Panji Asmara

email: gego@unika.ac.id;

Faculty of Medicine, Soegijapranata Catholic University

\author{
Yovita Arie Mangesti \\ email:yovitaam@untag-sby.ac.id
}

Faculty of Law University August 17, 1945 Surabaya

\begin{abstract}
The advancement of civilization has led to the creation of a dual form of the doctoradvocate profession which is confronted with many conflicts of interest between two opposing interests between doctors who are also advocates. This paper uses a legal, conceptual, and eclectic approach to positive law in the dual profession of doctor-advocate with humanitarian paradigm libertarianism. The results of this study resulted in the construction of the dual law of the doctor-advocate profession, providing an understanding that each individual has the right to decide on goals to be achieved based on morality and sensitivity to fair and civilized human values, so that in constructing the dual law of the doctor-advocate profession it is done only to defend the weak, without having to leave the identity and independence of the profession as doctors and advocates.
\end{abstract}

\section{Keywords:}

Abstrak: Kemajuan peradaban menghantar terciptanya bentuk profesi rangkap dokteradvokat yang dihadapkan pada sejumlah conflict of interest terhadap dua kepentingan yang berhadap-hadapan antara dokter yang juga berprofesi advokat. Tulisan ini menggunakan metode pendekatan perundang-undangan, konseptual dan eklektik terhadap hukum positif pada rangkap profesi dokter-advokat dengan batu uji libertarianisme berparadigma kemanusiaan. Hasil pengkajian ini menghasilkan konstruksi hukum rangkap profesi dokteradvokat, memberikan pemahaman bahwa setiap individu memiliki hak untuk memutuskan tujuan yang akan dicapai atas dasar moral dan kepekaan terhadap nilai kemanusiaan yang adil dan beradab, sehingga dalam mengkonstruksi hukum rangkap profesi dokter-advokat dilakukan hanya untuk membela kaum yang lemah, tanpa harus meninggalkan jati diri dan kemandirian profesi sebagai dokter dan advokat.

Kata kunci: profesi dokter, advokat, 
SOEPRA Jurnal Hukum Kesehatan

TERAKREDITASI RISTEKDIKTI Peringkat 4

ISSN:2548-818X (media online) Vol. 6 (1) Juni 2020

\section{PENDAHULUAN}

Manusia menjadi manusia seutuhnya ketika dia berada di tengah orang lain (sesamanya) dan mampu mengemban perannya sebagai bagian dari makhluk sosial. Profesi dokter dan profesi advokat merupakan profesi officium nobile, sehingga dalam meraih profesi tersebut seseorang harus menempuh kualifikasi pendidikan yang tak mudah. Ketika terjun di tengah masyarakat pun profesi ini dihadapkan pada berbagai segi kehidupan yang sarat dengan berbagai kepentingan. Profesi dokter sangat dekat dengan perbuatan hukum yang diatur tidak hanya dengan kode etik, namun juga dengan regulasi dalam Undang-undang, antara lain: Undang-Undang Praktik Kedokteran, Undang-Undang Kesehatan, Undang-undang tentang Rumah Sakit, dan segala peraturan lain yang terkait dalam upaya pelayanan medik. Demikian pula profesi advokat terikat erat dengan tidak hanya kode etik profesi, tetapi juga Undang-Undang Advokat dan peraturan lain di dalamnya.

Peran etika berada pada posisi yang berhimpitan dengan hukum. Artinya bahwa, etika sebagai norma moral yang abstrak ini perlu dipositivisasi dalam suatu aturan hukum. Pada konteks tujuan, hukum bermuara pada tiga tujuan yaitu: Keadilan, kemanfaatan dan kepastian. Pengaruh positivisme sangat kuat dalam berhukum, dimana keadilan, kepastian dan kemanfaatan itu akan tercapai jika nilai tersebut dinormakan, dan dipositivisasi secara konkrit dalam bentuk aturan yang lebih lanjut dikeluarkan dan disahkan oleh badan yang berwenang.

Di zaman ini yang terjadi bahwa seorang dokter (swasta) dapat juga berprofesi advokat. Penulis menyebut profesional tersebut sebagai rangkap profesi dokter-advokat. Komunitas ini membutuhkan seperangkat aturan yang spesifik mengatur peran dan kewenangan dalam bidang pelayanan profesionalnya. Kebutuhan ini tidak terlepas dari latar belakang ketika seseorang menjalankan profesinya. Profesi dokter mengutamakan kesembuhan bagi pasien, seringkali dihadapkan pada sejumlah risiko medik yang sangat mungkin sekali menuntut pertanggungjawaban terhadap dirinya selaku pemberi layanan medik. Profesi advokat, membela penerapan hukum bagi kliennya, yang dalam hal ini bisa saja seorang dokter, atau pasien yang sedang dirawat oleh dokter. Pada tataran ini, terlebih dengan semakin banyaknya sengketa di bidang kesehatan, bukan tidak mungkin seorang dokter juga adalah seorang advokat (rangkap profesi). Rangkap profesi dokter-advokat menjadi jawaban dari fenomena ini, mengingat kesadaran hukum seorang dokter yang semakin tinggi, dan semakin banyak ditemukan di berbagai belahan dunia, termasuk juga Indonesia.

Kode Etik Kedokteran Indonesia pada pasal 18 menyebutkan bahwa seorang dokter harus memperlakukan rekan sejawatnya sebagaimana dirinya sendiri ingin diperlakukan. Sedangkan Kode Etik Advokat Indonesia pada pasal 3 huruf b menyebutkan bahwa advokat harus mengutamakan tegaknya hukum, kebenaran dan keadilan. Seorang profesional dengan rangkap profesi dokter-advokat dihadapkan pada dilema (konflik peran) yang berimplikasi pada isu hukum. Konflik peran muncul saat seorang profesional dengan rangkap profesi dokter-advokat dalam kondisi membela kepentingan hukum kliennya, yang mana kliennya adalah pasien dari teman sejawatnya.

Konflik peran memunculkan sebuah perenungan mendalam seorang pribadi, mempertanyakan hakikat dirinya sebagai manusia yang tentunya berhak untuk melalui perziarahan hidup dengan caranya, otonom, mengikuti hati nurani dan keyakinan diri. Libertarianisme berpandangan bahwa individu sebagai seorang yang memiliki hak untuk mengendalikan diri mereka, bebas memilih dan menjalani hidup, selama tidak melanggar hak 
orang lain. ${ }^{1}$ Keadaan paradoksal ini menjadi fenomena conflict of interest seorang dokteradvokat. Sehingga muncullah suatu kebutuhan atas adanya hukum yang mampu mengakomodir dan memberikan perlindungan terhadap eksistensi rangkap profesi.

\section{RUMUSAN MASALAH}

Berdasar dari uraian di atas, tulisan ini akan mengkaji lebih dalam tentang Bagaimana konstruksi hukum rangkap profesi dokter-advokat Indonesia dengan menggunakan perspektif libertarian yang berparadigma kemanusiaan.

Penelitian ini bertujuan untuk menemukan hukum yang responsif untuk mengatasi conflict of interest dalam konteks membela kepentingan hukum pasien dari rekan sejawatnya.

\section{METODE PENELITIAN}

Penelitian merupakan penelitian hukum doktrinal dan bersifat preskriptif, ${ }^{2}$ dengan Pendekatan perundang-undangan (statute approach), konseptual (conceptual approach), dan eklektik (eclectik approach) digunakan untuk menganalisis hukum positif, yaitu: kode etik dokter Indonesia, kode etik advokat Indonesia, Undang-Undang terkait profesi dokter dan advokat dengan menggunakan sudut pandang libertarianisme. Selanjutnya, Pendekatan eklektik (eclectik approach), dilakukan dengan cara menyeleksi beberapa aspek dari berbagai pemikiran dan konsep, mengambil apa yang dinilai tepat dan bernilai dalam mengkonstruksi suatu pemikiran. ${ }^{3}$ Metode ini digunakan untuk membangun konstruksi hukum rangkap profesi dokter-advokat Indonesia yang menjunjung tinggi nilai kemanusiaan.

\section{PEMBAHASAN}

\section{A. Rangkap Profesi Dokter-Advokat dalam Perspektif Hukum Indonesia}

\section{Kode Etik Profesi}

Kode Etik merupakan norma atau asas yang diterima oleh suatu kelompok tertentu sebagai landasan tingkah laku sehari-hari di masyarakat maupun tempat kerja. ${ }^{4}$ Penyusunan kode etik dilakukan secara sistematis dan prinsip-prinsip moral suatu profesi yang melekat pada seseorang. Ibarat sebuah kompas, kode etik menunjukkan arah moral suatu profesi dan sebagai institusi penjamin mutu moral profesi di mata masyarakat luas. ${ }^{5}$

Kode etik profesi merupakan norma yang diterapkan dan diterima oleh kelompok profesi yang mengarahkan atau memberi petunjuk kepada anggotanya bagaimana seharusnya berbuat. Kode etik juga menjadi institusi penjaminan mutu moral profesi di mata masyarakat. ${ }^{6}$

\footnotetext{
${ }^{1}$ Firestone, R. S. (2017). An Argument for Libertarian Free Will: Hard Choices Based on either Incomparable or Equally Persuasive Reasons. Open Journal of Philosophy, 7, 64-93. https://doi.org/10.4236/ojpp.2017.71005

2 Soekanto Soerjono, Sri Mamudji, Penelitian Hukum Normatif, Radja Grafindo Persada, Jakarta, 2015, hlm 1.

3 Bagus, Lorens, Kamus Filsafat, Gramedia Pustaka Utama, Jakarta, 1996, hlm 182.

${ }^{4}$ Nuh, Muhammad, Etika Profesi Hukum, Pustaka Setia, Bandung, 2011, hlm 70.

5 Bertens, K, Etika, Kanisius, Yogyakarta, 2013, hlm 20.

${ }^{6}$ Mardani, Kode Etik Profesi Hukum, Rajawali Pers, Depok, 2017, hlm 98.
} 
Etika terapan memegang peranan penting. Kode etik dapat dilihat sebagai produk dari etika terapan karena merupakan penerapan pemikiran etis atas profesi. Kode etik ada, namun tak menjadikan pemikiran etis berhenti. Kode etik tidak menggantikan pemikiran etis, namun selalu didampingi oleh refleksi etis. Kode etik yang sudah ada, sewaktu-waktu harus dinilai kembali, dan bila perlu, kode etik dapat direvisi atau disesuaikan.7

\section{Regulasi tentang Kode Etik Advokat Indonesia}

Kode Etik Advokat Indonesia merupakan kode etik yang dikonstruksi bersama-sama oleh organisasi-organisasi profesi advokat yang ada di Indonesia pada Tahun 2002, tepatnya di sahkan pada Tanggal 23 Mei 2002. Organisasi-organisasi tersebut adalah Ikatan Advokat Indonesia (IKADIN), Asosiasi Advokat Indonesia (AAI), Ikatan Penasihat Hukum Indonesia (IPHI), Himpunan Advokat dan Pengacara Indonesia (HAPI), Serikat Pengacara Indonesia (SPI), Asosiasi Konsultan Hukum Indonesia (AKHI), Himpunan Konsultan Hukum Pasar Modal (HIKHPM). Semua organisasi profesi ini di dalam Komite Kerja Advokat Indonesia mengeluarkan Kode Etik Advokat. ${ }^{8}$

Kode Etik Advokat Indonesia tersusun secara sistematis, disusun dalam bab-bab yang terdiri dari pembukaan, ketentuan umum, kepribadian advokat, hubungan dengan klien, hubungan dengan teman sejawat, tentang sejawat asing, cara bertindak menangani perkara, ketentuan-ketentuan lain tentang kode etik, pelaksanaan kode etik, dewan kehormatan, kode etik dan hewan kehormatan, dan penutup.

Kode Etik Advokat Indonesia menyatakan bahwa profesi advokat adalah profesi yang terhormat (officium nobile) yang dalam menjalankan profesinya dibawah perlindungan hukum, undang-undang dan kode etik, memiliki kebebasan yang didasarkan kepada kehormatan dan kepribadian Advokat yang berpegang teguh kepada kemandirian, kejujuran, kerahasiaan, dan keterbukaan. Profesi advokat juga berkedudukan sebagai penegak hukum yang sejajar dengan instansi penegak hukum lainnya, sehingga harus saling menghargai antara teman sejawat dan para penegak hukum lainnya. Sumpah profesi sarat pengakuan dan kepatuhan terhadap kode etik yang berlaku.

Advokat dalam kode etiknya terkait dengan isu rangkap profesi tidak cukup jelas diatur. Pasal 3 huruf b Kode Etik Advokat Indonesia menyatakan "Advokat dalam melakukan tugasnya tidak bertujuan semata-mata untuk memperoleh imbalan materi tetapi lebih mengutamakan tegaknya hukum, kebenaran dan keadilan". Pasal 3 huruf c menyatakan "Advokat dalam menjalankan profesinya adalah bebas dan mandiri serta tidak dipengaruhi oleh siapapun dan wajib memperjuangkan hak-hak azasi manusia dalam Negara Hukum Indonesia." Pasal-pasal terkait kepribadian advokat ini mencerminkan betapa mulia nya profesi advokat, menjadi bangunan pondasi yang kokoh dalam memperjuangkan nilai-nilai kemanusiaan demi mencapai keadilan, kepastian, dan kemanfaatan hukum.

Perwujudan proses pencapaian keadilan, kepastian dan kemanfaatan hukum diatur dalam Undang-Undang Dasar Republik Indonesia Tahun 1945. Secara tegas menyatakan bahwa Negara Indonesia adalah negara hukum. Negara hukum menuntut adanya jaminan kesederajatan bagi setiap orang di hadapan hukum (equality before the

\footnotetext{
7 Bertens, K, Op.Cit, hlm 220.
}

${ }^{8}$ Kode Etik Advokat Indonesia 
law). Advokat sebagai profesi yang memperjuangkan kepentingan keadilan bagi masyarakat, juga diatur dalam Undang-Undang Republik Indonesia Nomor 18 Tahun 2003 tentang Advokat. Pasal 4 ayat 2 tentang sumpah advokat, penulis mengambil poin yang menegaskan bahwa: dalam melaksanakan tugas profesi sebagai pemberi jasa hukum akan bertindak jujur, adil, dan bertanggung jawab berdasarkan hukum dan keadilan (butir 3); dan advokat tidak akan menolak untuk melakukan pembelaan atau memberi jasa hukum di dalam suatu perkara yang menurut hematnya merupakan bagian daripada tanggung jawab profesi sebagai seorang Advokat (butir 6).

Pasal 33 Kode etik a quo menyatakan bahwa "Kode etik pada tanggal 23 Mei 2002 secara mutatis mutandis memiliki kekuatan hukum yang mengikat.

\section{Kode Etik Kedokteran Indonesia}

Kode Etik Kedokteran Indonesia (KODEKI) merupakan pedoman bagi dokter Indonesia anggota Ikatan Dokter Indonesia (IDI) dalam melaksanakan praktik kedokteran. ${ }^{9}$ KODEKI telah disesuaikan dengan situasi kondisi yang berkembang sesuai dengan kemajuan Ilmu Pengetahuan Teknologi Kedokteran dan dinamika etika global yang ada. KODEKI ini merupakan hasil rapat kerja nasional MKEK (Majelis Kehormatan Etik Kedokteran) yang diselenggarakan pada tanggal 3-4 Januari 2012.

KODEKI tersusun secara sistematis, disusun dalam bab-bab yang terdiri dari mukadimah, kewajiban umum, kewajiban dokter terhadap pasien, kewajiban dokter terhadap teman sejawat, kewajiban dokter terhadap diri sendiri, penjelasan KODEKI pasal demi pasal, dan penutup. KODEKI dilengkapi dengan penjelasan sebagai butirbutir konkrit yang menginterpretasikan secara tertutup pasal-pasal yang ada.

Dokter merupakan profesi yang dikenal sebagai profesi luhur tertua dalam sejarah karena dimensi tanggung jawabnya di bidang kemanusiaan yang membuahkan akhlak peradaban budaya sejagat. Norma etika yang dirumuskan dalam kode etik dibangun dengan pondasi ajaran filsafat tentang universalitas kewajiban dalam relasi sosial partikular dokter-pasien yang mengedepankan nilai-nilai tanggung jawab profesional, kesejawatan dan proporsionalitas tugas dan jasa dokter dalam rangka keberlangsungan profesi di era global. ${ }^{10}$

KODEKI mengatur kesejawatan pada pasal 18 dan 19. Pasal 18 menyatakan bahwa "Setiap dokter memperlakukan teman sejawatnya sebagaimana ia sendiri ingin diperlakukan". Cakupan pasal tersebut diantaranya meliputi hal-hal berikut, bahwa: Setiap dokter wajib berupaya untuk mencegah dan tidak memulai terjadinya konflik etikolegal di dalam dan/atau antar profesi dalam bentuk apapun serta dilarang bertengkar dengan sejawat pada saat tugas profesi (butir 4), Setiap dokter dilarang memberikan komentar negatif tentang sejawat lain pada saat di depan pasien/keluarganya (butir 6). Jlka dicermati, butir KODEKI ini diametral terhadap Kode Etik Advokat. Lebih lanjut, ketentuan ini justru melemahkan peran advokat yang juga berprofesi dokter.

Profesi dokter di Indonesia diatur dalam Undang-Undang Republik Indonesia Nomor 29 Tahun 2004 tentang Praktik Kedokteran. Keberadaan Undang-Undang ini adalah

\footnotetext{
${ }^{9}$ Surat Keputusan Pengurus Besar Ikatan Dokter Indonesia No.111/PB/A.4/02/2013 Tentang Penerapan Kode Etik Kedokteran Indonesia

${ }^{10}$ Kode Etik Kedokteran Indonesia Tahun 2012
} 
amanat dari Pembukaan Undang-Undang Dasar Negara Republik Indonesia Tahun 1945, bahwa pembangunan bidang kesehatan pada dasarnya ditujukan untuk meningkatkan kesadaran, kemauan dan kemampuan hidup sehat bagi setiap orang untuk mewujudkan derajat kesehatan yang optimal sebagai salah satu unsur kesehatan. Perangkat hukum ini mengatur penyelenggaraan praktik kedokteran dalam rangka memberikan kepastian hukum dan perlindungan hukum, untuk meningkatkan, mengarahkan dan memberi landasan hukum serta menata kembali berbagai perangkat hukum demi berjalannya praktik kedokteran yang sesuai dengan perkembangan ilmu pengetahuan dan teknologi. Kode etik dalam Undang-Undang Republik Indonesia Nomor 29 Tahun 2004 disebutkan sebagai salah satu pedoman yang harus ditaati oleh dokter, didasarkan pada disiplin ilmu kedokteran, selain tunduk pada ketentuan hukum yang berlaku.

4. Regulasi bagi Seorang Profesional dengan Rangkap Profesi Dokter-Advokat yang Membela Kepentingan Hukum Pasien dari Teman Sejawatnya

Ketika seseorang menjalani profesi sebagai sebagai dokter sekaligus advokat, semestinya diatur secara tersendiri. Saat ini belum ada regulasi rangkap profesi dokteradvokat tidak diatur secara eksplisit. Pada tataran praktis, terjadi posisi diametral di saat kepentingan hukum dokter dengan kepentingan hukum advokat dalam membela klien. Dokter advokat yang membela klien yang merupakan pasien dari teman sejawatnya, di mana dalam kode etik kedokteran Indonesia tercantum pada pasal 18 bahwa "Setiap dokter memperlakukan teman sejawatnya sebagaimana ia sendiri ingin diperlakukan." Cakupan pasal tersebut pada butir 4 disebutkan bahwa "Setiap dokter wajib berupaya untuk mencegah dan tidak memulai terjadinya konflik etikolegal di dalam dan/atau antar profesi dalam bentuk apapun serta dilarang bertengkar dengan sejawat pada saat tugas profesi."

Pisau analisa Teori Stufenbau ${ }^{11}$ menjadi salah satu perspektif yang dianggap penting dalam persoalan seperti ini. Teori Stufenbau yang dikemukakan oleh Hans Kelsen dan dikembangkan oleh Hans Nawiasky menyebutkan adanya suatu sistem hukum berupa sistem anak tangga dengan kaidah berjenjang, dimana norma hukum yang rendah harus berpegang pada norma hukum yang lebih tinggi. Hukum yang tertinggi menjadi norma yang paling mendasar (grundnorm), menjadi titik tolak hukum dibawahnya, menjadikan koherensi tiap aturan hukum yang ada.

Penerapan hukum berasaskan pada asas lex superior derogat legi inferior (aturan yang lebih tinggi mengesampingkan yang rendah), lex specialis derogat legi generalis (aturan yang bersifat khusus mengesampingkan aturan yang bersifat umum), lex posterior derogat legi priori (aturan yang sederajat, aturan yang paling baru mengesampingkan aturan yang lama).

Kode etik advokat dalam Undang-Undang Nomor 18 Tahun 2003 Pasal 33 menyatakan bahwa Kode Etik Advokat Indonesia mempunyai kekuatan hukum secara mutatis mutandis menurut Undang-Undang tersebut sampai ada ketentuan yang baru yang dibuat oleh Organisasi Advokat. Interpretasi ${ }^{12}$ terhadap keberadaan pasal ini

\footnotetext{
11 "The creation of one norm - the lower one - is determined by another - the higher - the creation of which is determined by a still higher norm, and that this regresses is terminated by a highest, the basic norm which being the supreme reason of validity of the whole legal order, constitutes in unity."

${ }^{12}$ Ricoeur, Paul, Teori Interpretasi, Membelah Makna dalam Anatomi Teks, Yogyakarta, 2014, hlm 194.
} 
menjadikan Kode Etik Advokat Indonesia memiliki kekuatan hukum yang mengikat, diberikan kekuatan hukum yang mengikat, sehingga menjadi aturan yang bersifat lebih tinggi dibandingkan dengan kode etik kedokteran. Dalam hal seorang profesional dengan rangkap profesi dokter-advokat yang membela kepentingan hukum pasien dari teman sejawatnya dibenarkan secara hukum, mengingat advokat sebagai sebuah profesi yang mengutamakan tegaknya hukum, kebenaran dan keadilan; bebas dan mandiri serta tidak dipengaruhi oleh siapapun dan wajib memperjuangkan hak-hak azasi manusia dalam Negara Hukum Indonesia.

\section{B. Elaborasi Libertarianisme dalam Konstruksi Hukum Rangkap Profesi Dokter-Advokat yang Sesuai dengan Nilai Kemanusiaan yang Adil dan Beradab}

Libertarianisme merupakan salah satu paham berdimensi keadilan yang diusung oleh Robert Nozick. Secara terminologis, kata libertarianisme berasal dari bahasa latin liber, yang bermakna bebas. Tujuan dan fokus utama dari penganut paham ini adalah menjunjung tinggi kebebasan sebagai nilai utama. ${ }^{13}$ "Individu bukanlah sekedar alat, melainkan tujuan akhir." Pandangan Kantian menjadi salah satu pokok pikiran yang diadopsi. ${ }^{14}$

Libertarianisme adalah teori dalam filsafat politik yang sangat menghargai kebebasan individu dan meragukan tentang ruang lingkup pemerintah yang dibenarkan dalam kehidupan kita. Libertarianisme memandang setiap individu sebagai individu yang berdaulat, sebagai individu yang memiliki hak untuk mengontrol diri sepenuhnya beserta seluruh pekerjaannya, yang bebas memutuskan bagaimana berinteraksi dengan orang lain, juga tidak dapat dipaksa untuk melakukan hal-hal yang bertentangan dengan kehendak mereka tanpa pembenaran yang sangat kuat. ${ }^{15}$ Komitmen untuk kebebasan dalam paham ini dapat dibenarkan dengan berbagai alasan, termasuk konsekuenalisme, hak alami, kontrak sosial, dan nilai- nilai kebebasan dari berbagai macam gangguan. ${ }^{16}$

Perlindungan sipil dan politik yang kuat semakin meyakinkan penganut paham libertarianisme terhadap konsep negara minimal yang ditawarkan. ${ }^{17}$ Negara minimal yang dimaksud adalah dengan adanya perlindungan kontrak antara individu dan kepemilikan privat melalui penegakan hukum, tanpa mencampuri hubungan antar warganya. ${ }^{18}$ Asumsi kunci yang dikemukakan oleh Nozick adalah kepemilikan privat. Keadilan ditentukan oleh apakah hak dihormati, bukanlah oleh pola keluaran akhir distribusi. ${ }^{19}$

\footnotetext{
13 Woodcock, George, Anarchism: A History Of Libertarian Ideas And Movements, Broadview Press, Peterborough, 2004, hlm. 16.

${ }^{14}$ Nozick, Robert, Anarchy, State, and Utopia, Basic Books, New York, 1974, hlm. 28 -29.

15 Bas Van Der Vossen, Libertarianism, Oxford Research Encyclopedia of Politics, 2017, DOI: 10.1093/acrefore/9780190228637.013.86, hlm. 1.

${ }^{16}$ Joseph Mazor dan Peter Vallentyne, Libertarianism, Left and Right, Oxford Handbooks Online, 2018, DOI: 10.1093/oxfordhb/9780199645121.013.3, hlm. 2.

${ }^{17}$ Bas Van Der Vossen, Op.Cit., hlm.2.

${ }^{18}$ Liana Endah Susanti, Kajian Terhadap Sila Keadilan dan Teori Keadilan Berfalsafah Libertarianisme dari Sudut Pandang Berideologi Pancasila, Yustitia Merdeka: Jurnal Ilmiah Hukum, 2018, ISSN: 24078778 , hlm. 103.

${ }^{19}$ Lebacqz, Karen, Teori-teori Keadilan, Nusa Media, Bandung, 1986, hlm.98.
} 
Konstruksi hukum (Rechtsconstructie), meliputi: ${ }^{20}$

1. Konstruksi Analogi, yaitu proses konstruksi yang dilakukan dengan cara mencari ratio legis (genus) dari suatu undang-undang dan kemudian menerapkannya kepada hal-hal lain yang sebenarnya tidak diatur oleh undang-undang itu. Konstruksi dibangun dengan cara memperluas keberlakuan suatu prinsip suatu ketentuan yang telah diabstraksikan pada suatu peristiwa.

2. Konstruksi Penghalusan Hukum (rechtsverfijning), yaitu bahwa apabila peraturan perundang-undangan yang ada tidak dapat digunakan dan atau mencederai nilai keadilan maka ketentuan hukum tertulis itu sebaiknya tidak diterapkan atau dipersempit lingkup berlaku suatu peraturan perundang-undangan (bersifat restriktif).

3. Konstruksi Argumentum a Contrario, yaitu menerapkan peraturan dengan menafsirkan atau menginterpretasikan sebaliknya dengan tetap menjunjung nilai keadilan.

4. Konstruksi Argumentum a Fortiori, yaitu menerapkan peraturan yang telah diabstraksi akibat hukumnya yang lebih berat, dengan melihat peraturan dengan akibat hukum yang jauh lebih ringan.

Bangunan konstruksi hukum rangkap profesi menurut hemat penulis dibangun di atas pondasi nilai kemanusiaan yang adil dan beradab. Konstruksi menjadi sebuah kebutuhan dalam rangka penemuan formulasi hukum yang tepat secara substansi, struktur dan budaya demi tercapainya tujuan hukum, yakni keadilan, kepasian, dan kemanfaatan hukum. ${ }^{21}$

Rangkap profesi pada zaman ini tidak dapat menjadi suatu hal yang terelakkan. Hukum haruslah mampu memprediksi tantangan sebagai tata hidup manusia, mengakomodir perkembangan daya pikir, akal manusia. Layaknya motto Descartes, cogito ergo sum, akal manusia sebagai aset terbesar pemberian Allah sang pencipta, pemilik dan pemberi kehidupan, pembeda dengan makhluk ciptaanNya yang lainnya, perkembangan ini haruslah dijawab oleh hukum, tanpa meninggalkan nilai-nilai Pancasila sebagai pegangan, pedoman hidup bangsa Indonesia.

Nilai kemanusiaan yang adil dan beradab diangkat oleh penulis sebagi batu uji dan titik tolak sebuah model konstruksi hukum rangkap profesi dokter-advokat. Sila Kedua Pancasila ini secara implisit menunjukkan adanya konsep keutuhan manusia dalam kesatuan rohaniah, keberadaan hati nurani tidak kalah penting daripada akal. ${ }^{22}$ Nilai kemanusiaan yang adil dan beradab terdiri dari butir-butir sebagai berikut ${ }^{23}$ :

1. Mengakui dan memperlakukan manusia sesuai dengan harkat dan martabatnya sebagai makhluk Tuhan Yang Maha Esa.

2. Mengakui persamaan derajad, persamaan hak dan kewajiban asasi setiap manusia, tanpa membeda-bedakan suku, keturrunan, agama, kepercayaan, jenis kelamin, kedudukan sosial, warna kulit dan sebagainya.

3. Mengembangkan sikap saling mencintai sesama manusia.

20 Shidarta, Hukum Penalaran dan Penalaran Hukum, Genta, Yogyakarta, 2013, hlm. 173.

${ }^{21}$ Bernard L Tanya, et al., Teori Hukum: Strategi Tertib Manusia Lintas Ruang dan Generasi, Genta, Yogyakarta, 2013, hlm. 118.

${ }^{22}$ Atmoredjo, Sudjito, Ideologi Hukum Indonesia: Kajian Tentang Pancasila dalam Perspektif Ilmu Hukum dan Dasar Negara Indonesia, Lingkar Media, Yogyakarta, 2018, hlm 92.

23 Kemanusiaan dalam cita hukum Indonesia, yang dijabarkan dalam Ketetapan MPR Nomor 1/MPR/2003 Tentang 45 (Empat Puluh Lima) Butir Pancasila 
4. Mengembangkan sikap saling tenggang rasa dan tepa selira.

5. Mengembangkan sikap tidak semena-mena terhadap orang lain.

6. Menjunjung tinggi nilai-nilai kemanusiaan.

7. Gemar melakukan kegiatan kemanusiaan.

8. Berani membela kebenaran dan keadilan.

9. Bangsa Indonesia merasa dirinya sebagai bagian dari seluruh umat manusia.

10. Mengembangkan sikap hormat menghormati dan bekerjasama dengan bangsa lain.

Butir-butir di atas menjadi sumber bagi aturan, regulasi yang ada. Nilai kemanusiaan dibangun atas dasar pemahaman hakikat manusia. Hakikat abstrak manusia "monopluralis" bersifat umum dan yang universal, tetap pada setiap manusia. Hakikat pribadi Indonesia sebagai keseluruhan sifat dan ciri yang khusus, khas, tetap, dan melekat pada diri manusia Indonesia. ${ }^{24}$ Selanjutnya, eksistensi manusia Indonesia itu baru muncul di saat dia memasuki kehidupan dan berinteraksi dengan sesamanya.

Kemanusiaan yang adil dan beradab diturunkan dalam butir-butir yang berimplikasi pada pengandalan keluruhan manusia dengan martabat dan kebebasannya. Bukan kebebasan semaunya sebebas-bebasnya, namun kebebasan dalam pengejaran dan pencapaian tujuan hidupnya. ${ }^{25}$ Kebebasan merupakan asal kodrat manusia, bermuara pada pengejaran kebaikan yang menjadi tujuan hidup manusia. ${ }^{26}$ Rangkap profesi sebenarnya merupakan suatu cara untuk mengakomodir kepentingan hukum masyarakat. Tujuan kebaikan yang sifatnya normatif ini membutuhkan konstruksi hukum positif sehingga kepastian hukum dapat tercapai.

Libertarianisme menjunjung tinggi kebebasan sebagai fokus utama dan sebagai tujuan. Aliran ini memaksimalkan otonomi dan kebebasan memilih, atas dasar nilai-nilai keutamaan individu. Rangkap profesi dokter-advokat merupakan gabungan dua peran sosial dalam diri seseorang yang didapatkan setelah ia menjalani suatu pendidikan profesi dengan kompetensi yang berbeda satu dengan lainnya. Dokter tunduk pada Kode etik sedangkan advokat tunduk pada Undang-Undang Advokat. Pedoman perilaku, meski dibangun berdasar nilai kemanusiaan dan keadilan, berpotensi terjadi benturan kepentingan karena masing-masing professional berada pada posisi diametral. Pada rangkap profesi ini, libertarianisme memberikan pemahaman bahwa setiap individu memiliki hak untuk memutuskan tujuan yang akan dicapai atas dasar moral dan kepekaan terhadap nilai kemanusiaan dan keadilan sehingga dalam mengkonstruksi hukum Rangkap Profesi Dokter-advokat, dicantumkan bahwa Rangkap Profesi dilakukan hanya untuk membela kaum lemah (vulnerable person) tanpa harus meninggalkan jati diri dan kemandirian profesi sebagai dokter dan advokat.

\footnotetext{
${ }^{24}$ Kaelan, Filsafat Pancasila Pandangan Hidup Bangsa Indonesia, Paradigma, Yogyakarta, 2002, hlm 177.

${ }^{25}$ Mangesti, Yovita Arie, Perlindungan Hukum Berparadigma Kemanusiaan yang Adil dan Beradab pada Riset dan Pemanfaatan Human Stem Cell (Sel Punca Manusia) di Bidang Kesehatan, Disertasi, Universitas Sebelas Maret, Surakarta, 2015, hlm 55.

${ }^{26}$ Armada Riyanto dalam "Berkat dari Litan dan Kemanusiaan Indonesia", Armada Riyanto, et.al, Kearifan Lokal Pancasila Butir-butir Filsafat Keindonesiaan, Kanisius, Yogyakarta, 2015, hlm 172.
} 
Bentuk konstruksi hukum yang penulis tawarkan sebagai sebuah solusi adalah dibentuknya Undang-Undang Rangkap Profesi. Konsruksi yang penulis tewarkan ini dapat berlaku juga bagi profesi lainnya yang mungkin bermunculan sebagai dampak perkembangan zaman. Secara substansif Undang-Undang ini berisi tentang:

1. Definisi rangkap profesi

Definisi tentang rangkap profesi ini akan memberikan batasan secara eksplisit tentang profesi apa yang dimaksud dan diatur dalam regulasi. Definisi rangkap profesi merupakan hal dasar yang sangat penting. Definisi menjadi sebuah pembatas yang jelas, sehingga pemaknaannya menjadi tepat. Perihal rangkap profesi dokter-advokat, di lapangan yang dapat dijumpai adalah seorang dokter yang kemudian juga menjadi advokat, mengingat pendidikan ilmu hukum yang masih mungkin untuk ditempuh, persyaratan umum seperti umur, batas waktu setelah lulus menempuh pendidikan sekolah menengah atas, dan lain sebagainya.

2. Persyaratan rangkap profesi

Bagian ini berisi tentang syarat kompetensi yang harus dimiliki oleh profesional, berasal dari kedua komunitas. Pada rangkap profesi dokter advokat, persyaratan yang mendasar adalah sertifikasi kompetensi sebagai dokter dan sebagai advokat telah disumpah di pengadilan tinggi. Untuk menjamin profesionalitas dan mutu diri, maka rangkap profesi ini secara berkala ada evaluasi kompetensi.

3. Hak rangkap profesi

Hak rangkap profesi dapat diinterpretasikan secara luas sebagai bentuk kewenangan. Kewenangan menjadi suatu hal yang spesial karena tidak melekat dan diberikan kepada banyak orang, hanya orang yang berada dalam ruang lingkup rangkap profesi tersebut. Hak merupakan hak-hak profesi, yang sekaligus hak konstitusional dari profesi yang diberikan oleh negara.

4. Kewajiban terhadap klien

Hak selalu diiringi dengan kewajiban. Keberadaan kewajiban pada aras normatif menunjukkan pada hal-hal yang menjadi perintah yang harus dijalankan. Pada tatanan hukum, kewajiban menjadi produk penguasa (pemerintah) untuk profesi rangkapprofesi demi tercapainya cita hukum. Kewajiban terhadap klien sebenarnya merupakan pemenuhan kepentingan masyarakat.

Rumusan kewajiban terhadap klien ini menggambarkan paradigma hukum yang didasarkan atas kemanusiaan yang adil dan beradab. Artinya dengan kewajiban ini memberikan jaminan yang harus diberikan kepada klien bahwa akan mendapatkan pelayanan proporsional, perlindungan sebagai vulnerable person. Kewajiban ini menempatkan klien sebagai subyek, bukan sebagai obyek.

Rangkap profesi wajib untuk mendampingi kliennya, hanya demi kepentingan klien. Jika harus bertentangan dengan rekan sejawatnya, ini dimungkinkan karena dasar yang dipakai adalah mendekati kebenaran materil dari suatu tindakan pelanggaran hukum atau sengketa atas hukum.

Kewajiban ini disertai dengan penyadaran bahwa klien apakah itu dia sebagai korban ataukah tersangka / pelaku; apakah dia sebagai pihak rumah sakit atau pihak yang dirugikan, keseluruhan haruslah dipandang sebagai manusia yang juga memiliki harkat 
dan martabatnya. Hal ini penting disadari untuk meletakkan suatu permasalahan secara tepat tanpa harus mencederai keadaban.

5. Mekanisme penyelesaian perkara rangkap profesi

Mekanisme penyelesaian perkara merupakan bagian yang juga penting, sebagai bentuk perlindungan hukum yang tak terpisahkan. Perlindungan hukum adalah suatu perbuatan/tindakan yang memberikan perlindungan kepada subyek hukum. Hubungan antar subyek hukum lahir dari tindakan-tindakan hukum, sebagai daya dukung dari hak dan kewajiban. ${ }^{27}$ Penyelesaian sengketa yang terjadi terkait rangkap profesi, jika ini merupakan pelanggaran etik, maka dapat diselesaikan di kolegium profesinya. Dalam hal profesi rangkap, ke depan, ada baiknya membentuk organisasi rangkap profesi dengan perangkan Dewan Kehormatan Rangkap Profesi. Dewan ini berwenang memutuskan ada atau tidaknya pelanggaran etik dan hukum, Ketika dijumpai adanya pelanggaran etik, maka penyelesaiannya dikkuakan dengan mediasi dan sanksinya dapat berupa peringatan, pencabutan izin. Anggota dewan kehormatan adalah profesional dari kalangan advokat, dokter, para pakar di bidang etikomedikolegal.

Apabila terjadi pelanggaran hukum, karena regulasi kode etik rangkap profesi ini dapat berbentuk Undang-undang, maka untuk penyelesaian secara litigasi, tunduk pada ketentuan menurut hukum formil, dengan dengan sanksi hukuman pokok dan hukuman tambahan.

Konstruksi yang penulis kemukakan di atas hanyalah sebuah konsep atau tataran normatif. Masih dibutuhkan pengkajian lebih lanjut dari segi rumusan bahasa perundangundangan, tetapi secara substansial, dibutuhkan hukum dengan norma-norma kemanusiaan yang adil dan beradab, dalam berbagai bentuk dan upaya penegakannya.

\section{KESIMPULAN}

Tindakan seorang profesional dengan rangkap profesi dokter-advokat yang membela kepentingan hukum pasien dari teman sejawatnya adalah benar demi mengutamakan tegaknya hukum, kebenaran dan keadilan. Elaborasi libertarianisme berparadigma Pancasila dalam konstruksi hukum rangkap profesi dokter-advokat memberikan pemahaman bahwa setiap individu memiliki hak untuk memutuskan tujuan yang akan dicapai atas dasar moral dan kepekaan terhadap nilai kemanusiaan yang adil dan beradab, sehingga dalam mengkonstruksi hukum rangkap profesi dokter-advokat dilakukan hanya untuk membela kaum yang lemah, tanpa harus meninggalkan jati diri dan kemandirian profesi sebagai dokter dan advokat. Konstruksi hukum rangkap profesi dokter-advokat secara substansial mencakup: Definisi rangkap profesi, persyaratan rangkap profesi, hak rangkap profesi, kewajiban terhadap klien, dan mekanisme penyelesaian perkara rangkap profesi.

\footnotetext{
27 Mangesti, Yovita Arie, Hukum Berparadigma Kemanusiaan: Perlindungan Riset dan Pemanfaatan Human Stem Cell, Genta, Yogyakarta, 2016, hlm 20.
} 


\section{SARAN}

1. Bagi kalangan praktisi dokter dan advokat, perlu adanya regulasi setingkat undangundang rangkap profesi, sehingga dalam melaksanakan tugasnya, seorang dokter yang juga advokat memiliki dasar untuk berpijak secara yuridis.

2. Bagi masyarakat, khususnya pasien hendaknya semakin menyadari bahwa segala hal terkait pelayanan profesional memiliki wadah / badan hukum untuk dapat menjadi sarana bagi permasalahan hukum yang ada.

3. Bagi penegak hukum, pada persoalan perjanjian terapeutik, hendaknya dapat mengutamakan kepentingan kaum lemah, miskin, tua, difabel, atau pihak mana saja yang terdominasi, untuk tercapainya nilai kemanusiaan, keadilan dan keadaban.

\section{DAFTAR PUSTAKA}

Buku

Armada Riyanto dalam "Berkat dari Litan dan Kemanusiaan Indonesia", Armada Riyanto, et.al, Kearifan Lokal Pancasila Butir-butir Filsafat Keindonesiaan, Kanisius, Yogyakarta, 2015

Atmoredjo, Sudjito, Ideologi Hukum Indonesia: Kajian Tentang Pancasila dalam Perspektif Ilmu Hukum dan Dasar Negara Indonesia, Lingkar Media, Yogyakarta, 2018

Bagus, Lorens, Kamus Filsafat, Gramedia Pustaka Utama, Jakarta, 1996

Bernard L Tanya, et al., Teori Hukum: Strategi Tertib Manusia Lintas Ruang dan Generasi, Genta, Yogyakarta, 2013

Bertens, K, Etika, Kanisius, Yogyakarta, 2013

Kaelan, Filsafat Pancasila Pandangan Hidup Bangsa Indonesia, Paradigma, Yogyakarta, 2002

Lebacqz, Karen, Teori-teori Keadilan, Nusa Media, Bandung, 1986

Mangesti, Yovita Arie, Hukum Berparadigma Kemanusiaan: Perlindungan Riset dan Pemanfaatan Human Stem Cell, Genta, Yogyakarta, 2016

Mangesti, Yovita Arie, Perlindungan Hukum Berparadigma Kemanusiaan yang Adil dan Beradab pada Riset dan Pemanfaatan Human Stem Cell (Sel Punca Manusia) di Bidang Kesehatan, Disertasi, Universitas Sebelas Maret, Surakarta, 2015

Mardani, Kode Etik Profesi Hukum, Rajawali Pers, Depok, 2017

Nozick, Robert, Anarchy, State, and Utopia, Basic Books, New York, 1974

Nuh, Muhammad, Etika Profesi Hukum, Pustaka Setia, Bandung, 2011

Ricoeur, Paul, Teori Interpretasi, Membelah Makna dalam Anatomi Teks, Yogyakarta, 2014

Shidarta, Hukum Penalaran dan Penalaran Hukum, Genta, Yogyakarta, 2013

Soekanto Soerjono, Sri Mamudji, Penelitian Hukum Normatif, Radja Grafindo Persada, Jakarta, 2015

Woodcock, George, Anarchism: A History Of Libertarian Ideas And Movements, Broadview Press, Peterborough, 2004 
Jurnal

Bas Van Der Vossen, Libertarianism, Oxford Research Encyclopedia of Politics, 2017, DOI: 10.1093/acrefore/9780190228637.013.86

Firestone, R. S. (2017). An Argument for Libertarian Free Will: Hard Choices Based on either In- comparable or Equally Persuasive Reasons. Open Journal of Philosophy, 7, 64-93. https://doi.org/10.4236/ojpp.2017.71005

Hadjon, Philipus M, Pengkajian Ilmu Hukum, Makalah pada Penataran dan Lokakarya "Menggagas Format Usulan dan Laporan Penelitian Hukum Normatif", Fakultas Hukum Universitas Brawijaya, Malang, 1997

Joseph Mazor dan Peter Vallentyne, Libertarianism, Left and Right, Oxford Handbooks Online, 2018, DOI: 10.1093/oxfordhb/9780199645121.013.3

Liana Endah Susanti, Kajian Terhadap Sila Keadilan dan Teori Keadilan Berfalsafah Libertarianisme dari Sudut Pandang Berideologi Pancasila, Yustitia Merdeka: Jurnal Ilmiah Hukum, 2018, ISSN: 2407-8778

Peraturan Perundang-Undangan

Undang-Undang Nomor 18 Tahun 2003 Tentang Advokat

Undang-Undang Nomor 29 Tahun 2004 Tentang Praktik Kedokteran

Ketetapan MPR Nomor 1/MPR/2003 Tentang 45 (Empat Puluh Lima) Butir Pancasila

Surat Keputusan Pengurus Besar Ikatan Dokter Indonesia No.111/PB/A.4/02/2013 Tentang Penerapan Kode Etik Kedokteran Indonesia

Kode Etik Advokat Indonesia

Kode Etik Kedokteran Indonesia 